\title{
ON THE OCCURRENCE OF SCYPHOZOAN EPHYRAE (CNIDARIA, SCYPHOZOA, SEMAEOSTOMEAE AND RHIZOSTOMEAE) IN THE SOUTHEASTERN BRAZILIAN COAST
}

\author{
Valquiria Baddini Tronolone $e^{1,2}$ (correspondence author; autor para correspondência); André Carrara Morandini ${ }^{2}$ \\ and Alvaro Esteves Migotto ${ }^{1,2}$
}

Biota Neotropica v2 (n2) - http://www.biotaneotropica.org.br/v2n2/pt/abstract?article+BN02102022002

\author{
Date Received 07/04/2002 \\ Revised 08/03/2002 \\ Accepted 10/02/2002
}
${ }^{1}$ Centro de Biologia Marinha, Universidade de São Paulo, Caixa Postal 83, 11600-970, São Sebastião, SP, Brasil. Tel.:+55-12-38627149Fax:+55-12-4626646
${ }^{2}$ Departamento de Zoologia, Instituto de Biociências, Universidade de São Paulo, Caixa Postal 11461, 05422-970, São
Paulo, SP, Brasil.
Tel.:+55-11-30917619Fax:+55-11-30917513
e-mails: valbadtr@usp.br, acmorand@usp.br, aemigott@usp.br

\begin{abstract}
The occurrence of ephyrae of the scyphozoan orders Semaeostomeae and Rhizostomeae is reported for the first time for the Brazilian coast. The specimens, caught in plankton tows in the São Sebastião Channel and the Cananéia lagoon estuarine system, are: Chrysaora lactea (Semaeostomeae), Phyllorhiza punctata (Rhizostomeae), and an unidentified species of Pelagia (Semaeostomeae). A table with all species of scyphozoan with the known life cycle is provided.
\end{abstract}

Palavras-chave : Scyphozoa, Semaeostomeae, Rhizostomeae, ephyra, life cycle, Brazil.

Resumo - A ocorrência de éfiras de cifozoários das ordens Semaeostomeae e Rhizostomeae é registrada pela primeira vez para a costa brasileira. Os espécimes, coletados com arrastos de plâncton no Canal de São Sebastião e no Sistema estuarino-lagunar de Cananéia, são: Chrysaora lactea (Semaeostomeae), Phyllorhiza punctata (Rhizostomeae), e uma espécie não identificada de Pelagia (Semaeostomeae). Uma tabela, com todas as espécies de cifozoários com ciclo de vida conhecido, é apresentada.

Palavras-chave : Scyphozoa, Semaeostomeae, Rhizostomeae, éfira, ciclo de vida, Brasil. 


\section{Introduction}

The class Scyphozoa is defined, besides other features, by the process of strobilation (Schuchert, 1993), i.e. successive vegetative (asexual reproduction) cutting-off of a sequence of new individuals (ephyrae) from one end of a parent benthic polyp (scyphistomae) (Mianzan \& Cornelius, 1999: 525, the text in parenthesis was added). These disks (ephyrae) are the young (immature) free-swimming stages of the scyphozoans (Stachowitsch, 1992). Strobilation can be divided into monodisc (one disc produced at a certain time) or polydisc (more than one disc produced at a certain time) (Arai, 1997).

In the life cycle of Stylocoronella riedli and $S$. variabilis (members of the order Stauromedusae), the interstitial polyp metamorphoses into a medusa (see Kikinger \& Salvini-Plawen, 1995), thus not presenting an ephyra stage. Collins (2002) proposed that the Stauromedusae be separated from the other Scyphozoa, due to the absence of the strobilation process and, consequently, not producing ephyrae. The absence of strobilation and ephyrae, plus the presence of a claustrum led several authors to the conclusion that the Stauromedusae are closely related to the class Cubozoa (cf. Haeckel, 1880; Uchida, 1929; one topology found by Collins, 2002).

Some scyphomedusae present a holopelagic life cycle (absence of the polyp stage, and thus, of strobilation), e.g., the semaeostome Pelagia noctiluca (see Rottini Sandrini $\&$ Avian, 1983) and the coronate Periphylla periphylla (see Jarms et al., 1999).

Besides the general morphological similarity of the ephyra stage of most species, which makes their specific identification difficult, there are few life cycle studies of Scyphozoa, that include detailed accounts of this planktonic stage, to rely on. Out of $c a .200$ species of scyphozoans (Mianzan \& Cornelius, 1999), only about 42 species (almost a quarter of those known) had their life cycles described (see Table 1 in Results and Discussion). Russell (1970) provided a comparative plate of the ephyra stages of the British species. Even among the works devoted to the life cycle of scyphozoan species, only a few [e.g., Silveira \& Morandini (1997) and Jarms (2001), for Coronatae; Avian (1986) and Pitt (2000), for Rhizostomeae; Calder (1972) and Gershwin \& Collins (2002), for Semaeostomeae] included descriptions of ephyrae. For some species, information concerning life cycle stages is scattered throughout the literature, included in systematic or faunistc reports among descriptions of other species, or referring to one or another stage only.

None of the 23 scyphozoans recorded for Brazil (see Migotto et al., 2002) refer to ephyrae collected in nature. Despite their efforts, Silveira \& Morandini (1998) could not find the ephyra and medusa of the coronate Linuche unguiculata, a species associated with a calcareous substrate and abundant in the region of São Sebastião. Goy (1979) mentioned the presence of young specimens of Chrysaora lactea (as C. hysoscella) on the coast of Uruguay, and young Aurelia aurita on the coast of Bahia State (Brazil).

This work reports and describes three different ephyrae found on the southeastern coast of Brazil. A table covering the knowledge from literature and our own experiences in life cycles of Scyphozoa (except Stauromedusae) is provided.

\section{Material and Methods}

Specimens came from two localities on the coast of São Paulo State, southeastern Brazil: the São Sebastião Channel $\left(23^{\circ} \mathrm{S}-45^{\circ} \mathrm{W}\right)$ (SSC) and the Cananéia lagoon estuarine system $\left(25^{\circ} \mathrm{S}-48^{\circ} \mathrm{W}\right)(\mathrm{CES})$ (see Figure 1).

In the SSC, two ephyrae were collected with vertical plankton tows (300 and $500 \mu \mathrm{m}$ mesh sizes; maximum depth $40 \mathrm{~m}$ ) in August and October 1999, and reared in the laboratory until the first signs of gonadal tissue were detected. The ephyrae were isolated in glass containers filled with filtered seawater (changed daily) and kept in a constant temperature chamber at $20-21^{\circ} \mathrm{C}$. The medusae were fed daily with Artemia sp. nauplii, besides other planktonic organisms (especially copepods) and small pieces of muscle and gonads of mussels (Perna perna).

In the CES, ephyrae were collected with horizontal ( $0.5 \mathrm{~m}$ below surface) and vertical (maximum depth $12 \mathrm{~m}$ ) plankton tows (500 and $200 \mu \mathrm{m}$ mesh sizes) in April 2001, and January and February 2002. The ephyrae were transferred to culture dishes, kept in a constant temperature chamber at $22^{\circ} \mathrm{C}$ and reared as described by Jarms et al. (in press). Mature medusae of Chrysaora lactea collected at CES and reared in "planktonkreisel" (according to Greve, 1968) produced planulae that settled on the "planktonkreisel" walls and originated scyphistomae; these were transferred to culture dishes, there producing ephyrae.

Fixed and live specimens were photographed under a stereomicroscope; the live ones were relaxed in a mixture of $1: 1$ of seawater and $7.5 \% \mathrm{MgCl}_{2}$ solution before being photographed. When the specimens from the SSC attained a size larger than $15 \mathrm{~mm}$ in diameter they were also periodically photographed, without being anaesthetized, in an aquarium using a $35 \mathrm{~mm}$ camera and a flashgun. 


\begin{tabular}{|c|c|c|c|}
\hline Class & Order & Species & $\begin{array}{c}\text { Reference } \\
\end{array}$ \\
\hline \multirow[t]{42}{*}{ SCYPHOZOA } & CORONATAE & Atorella japonica & Kawaguti \& Matsuno 1981 \\
\hline & & Atorella vanhoeffeni & Werner 1966 \\
\hline & & Linuche unguiculata & Ortiz-Corp's et al. 1987 \\
\hline & & Nausithoe aurea & Silveira \& Morandini 1997 \\
\hline & & Nausithoe eumedusoides & Werner 1974 \\
\hline & & Nausithoe globifera & Jarms 1997 \\
\hline & & Nausithoe hagenbecki & Jarms 2001 \\
\hline & & Nausithoe maculata & Jarms 1990 \\
\hline & & Nausithoe marginata & Jarms 1990 \\
\hline & & Nausithoe planulophora & Werner \& Hentschel 1983 \\
\hline & & Nausithoe punctata & Werner 1979 \\
\hline & & Nausithoe racemosa & Komai \& Tokuoka 1939 \\
\hline & & Nausithoe thieli & Jarms 1990 \\
\hline & & Nausithoe werneri & Jarms 1990 \\
\hline & & Periphylla periphylla & Jarms et al. 1999 \\
\hline & & Thecoscyphus zibrowii & Sötje \& Jarms 1999 \\
\hline & SEMAEOSTOMEAE & Aurelia aurita & Lucas 2001 \\
\hline & & Aurelia labiata & Gershwin 2001 \\
\hline & & Chrysaora achlyos & *Gershwin \& Collins 2002 \\
\hline & & Chrysaora colorata & Gershwin \& Collins 2002 \\
\hline & & Chrysaora fuscescens & *Gershwin \& Collins 2002 \\
\hline & & Chrysaora hysoscella & *Delap 1901 \\
\hline & & Chrvsaora melanaster & Kakinuma 1967 \\
\hline & & Chrysaora quinquecirrha & Littleford 1939; Calder 1972 \\
\hline & & Cyanea capillata & *Gröndahl 1988 \\
\hline & & Cyanea lamarckii & *Gröndahl 1988 \\
\hline & & Pelagia noctiluca & Goette 1893; Russell 1970 \\
\hline & & Phacellophora camtschatica & $\begin{array}{l}\text { *Wrobel \& Mills } 1998 \text { (picture of } \\
\text { the polyp stage, p.22) }\end{array}$ \\
\hline & & Sanderia malayensis & Uchida \& Sugiura 1978 \\
\hline & & Stygiomedusa fabulosa & Russel \& Rees 1960 \\
\hline & RHIZOSTOMEAE & Cassiopea andromeda & Gohar \& Eisawy 1960 \\
\hline & & Cassiopea xamachana & Bigelow 1900 \\
\hline & & Catostylus mosaicus & Pitt 2000 \\
\hline & & Cephea cephea & *Sugiura 1966 \\
\hline & & Cotylorhiza tuberculata & Kikinger 1992 \\
\hline & & Mastigias papua & Uchida 1926 \\
\hline & & Phyllorhiza punctata & Lange \& Kaiser 1995 \\
\hline & & Rhizostoma pulmo & *Paspaleff 1938 \\
\hline & & Rhopilema esculenta & Ding \& Chen 1981 \\
\hline & & Rhopilema nomadica & Lotan et al. 1992 \\
\hline & & Rhopilema verrilli & Calder 1973 \\
\hline & & Stomolophus meleagris & Calder 1982 \\
\hline
\end{tabular}

Table 1. Scyphozoan species with known life cycles (except Stauromedusae), adapted from several sources. The most recent references or those with the most complete description regarding their life cycle were included. A reference which mentions one or another stage was included and marked with an "**". 

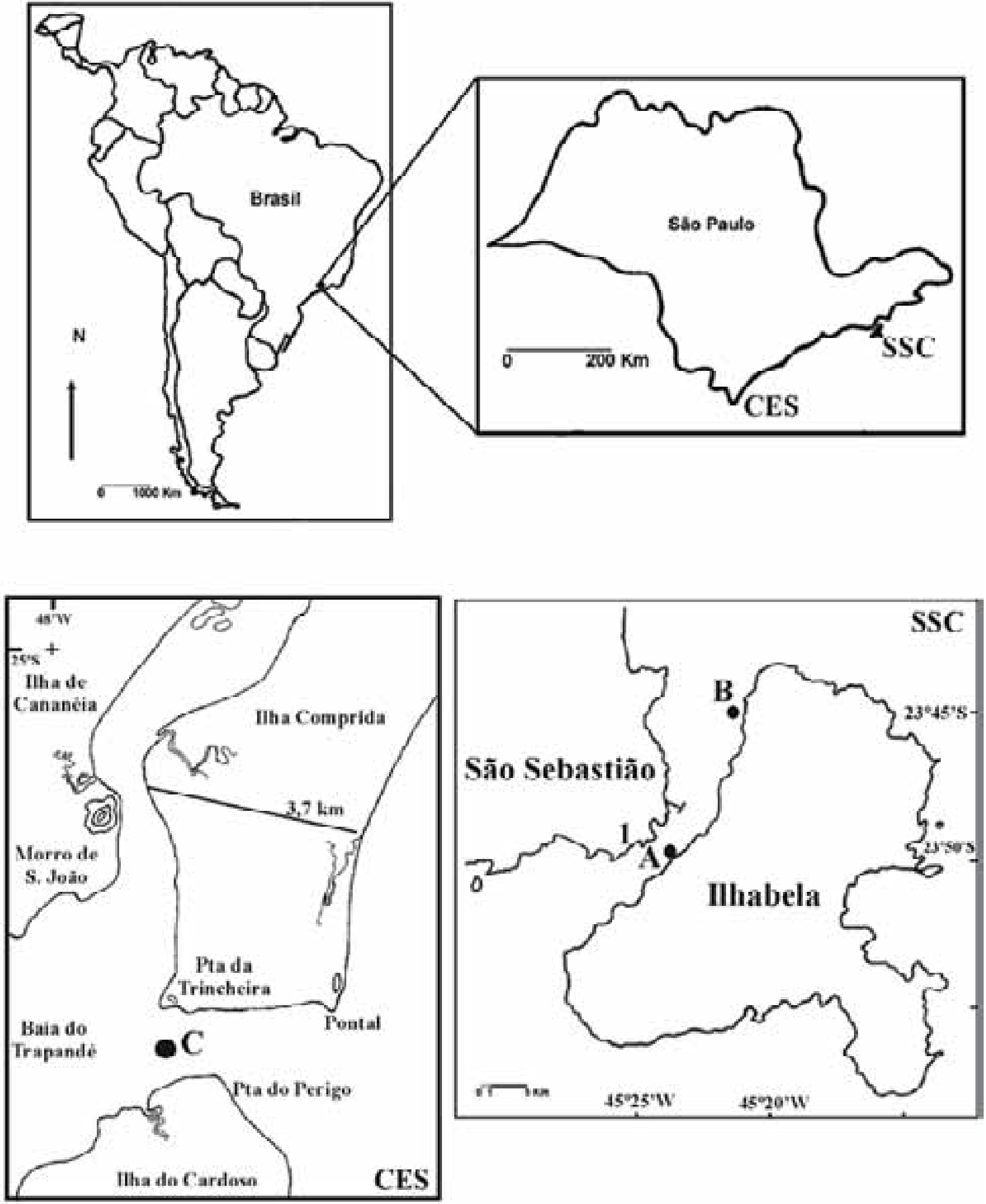

Figure 1. Map showing the collecting areas: CES = Cananéia lagoon estuarine system; SSC = São Sebastião Channel; $1=$ Centro de Biologia Marinha laboratory (CEBIMar-USP); A= collection of Chrysaora lactea $\left(23^{\circ} 49.89 S-045^{\circ} 25.36 \mathrm{~W}\right) ; B=$ collection of Pelagia $\left(23^{\circ} 44.85 S-045^{\circ} 20.92 \mathrm{~W}\right) ; C=$ collection of Phyllorhiza punctata. 


\section{Results and Discussion}

\section{Known life cycle}

A review of scyphozoan literature was performed to build up a list with all scyphozoan species (except for the order Stauromedusae) in which the life cycle is known. This list is presented here as Table 1 . We tried to provide the most complete or the most recent reference for each species. But, for some of them there is little information on life cycle stages, and we decided to include references which mentioned one or another stage (these are marked with a "*" in the table). As mentioned in the Introduction, life cycles have been described of only about 42 species, this means almost a quarter of the known scyphozoan species. The order with more species with known life cycles is Coronatae (16 spp.), followed by Semaeostomeae (14 spp.), the last being Rhizostomeae (12 spp.).

\section{Order Rhizostomeae}

Phyllorhiza punctata von Lendenfeld, 1884

Seven specimens (Figure 2), found in the waters of CES (salinity 20-24\%o; temperature $28^{\circ} \mathrm{C}$ ) measuring 1.5-2.5 $\mathrm{mm}$ in diameter when collected, were reared for 54 days. Their tissues were filled with zooxanthellae, and they presented 8 lobes with rounded lappets and 4 gastric filaments; some specimens had small warts on the exumbrella. By the $7^{\text {th }}$ day (Figure 3), the marginal lappets started to grow between the lobes, and the manubrium became more elongated. By the $10^{\text {th }}$ day the oral arms showed the first signs of oral tentacles and began to bifurcate. On the $40^{\text {th }}$ day the mouth closed and the exumbrellar warts were more conspicuous.

These ephyrae were identified as Phyllorhiza punctata by the presence of zooxanthellae and the white warts on the exumbrella. In the same period that the studied specimens were found, large medusae were also present in the area. Ephyrae obtained from laboratory cultures measured $1.5 \mathrm{~mm}$ when detached from the scyphistomae, suggesting that the specimens collected in the plankton tows had been newly released. Although recent articles (Garcia, 1990; Rippingale \& Kelly, 1995) mention the occurrence of the ephyrae stage of $P$. punctata, until now there is no morphological description of it in the literature. D'Ambra et al. (2001) commented on the flow and prey capture of young $P$. punctata (1.4-7.4 cm in diameter).

\section{Order Semaeostomeae}

\section{Chrysaora lactea Eschscholtz, 1829}

One ephyra (Figure 4a) was found in SSC (salinity: $34 \%$; temperature $20.8^{\circ} \mathrm{C}$ ), and reared for 38 days. When collected it had a transparent body, was $1.2 \mathrm{~mm}$ in diameter, had a manubrium with red pigment spots, pointed lappets ( 3 lappets were probably damaged during collecting, regenerated during the first week), and nematocyst clusters at the base of each marginal lappet (i.e., in the typical Chrysaorapattern, cf. Russell, 1970; Gershwin \& Collins, 2002). From days 10-19 the beginning of the 8 marginal tentacles were noted, and from days 20-29 the pigmentation of the manubrium became pale and smaller (Figure 5). From days 30-37, 5-9 gastric filaments were observed in each quadrant. At the $38^{\text {th }}$ day the young medusa reached a diameter of $2 \mathrm{~cm}$ and the manubrium a length of $4 \mathrm{~cm}$ (Figure 6). At this stage, secondary tentacle buds were observed growing from below the lappets (Figure 7), totaling 24 tentacles.

The number of tentacles and the nematocyst clusters arranged in a pattern are diagnostic characters of Chrysaora; as the only species of the genus that occurs on the Brazilian coast is Chrysaora lactea, the specimen is identified as that. With this, secondary tentacles arising below the marginal lappets are diagnostic characters of $C$. lactea. The ephyrae obtained in the laboratory from mature medusae of $C$. lactea collected at CES were identical to the nature-collected specimen, except for the lack of pigmentation (Figure 4b). Calder (1972) noted that ephyra of $C$. quinquecirrha obtained from scyphistomae raised in the laboratory had no pigmentation. Little information on the biology of the species exists. Mianzan (1989a, 1989b) mentioned that some ephyrae of C. lactea were collected in plankton tows along the Argentinean coast.

\section{Pelagia Péron \& Lesueur, 1810}

One ephyra (Figure 8 ), found in the waters of SSC (salinity: $34-36 \%$; temperature: $20.5^{\circ} \mathrm{C}$ ), had a diameter of $2.4 \mathrm{~mm}$ when collected. It was reared for 76 days. In the laboratory, from days 1-19, it acquired 2 gastric filaments, 4 milky spots on the stomach, red pigment on the manubrium and nematocyst clusters around the central disk. From days 20-39, 2 marginal tentacles and 4-5 gastric filaments on each quadrant developed, the manubrium attained a length of 4.3 $\mathrm{mm}$, and warts on the umbrella and manubrium (Figure 9) were visible; at the same time the milky spots on the stomach disappeared. From days 40-70 many gastric filaments (up to 10 in each quadrant) were observed in each quadrant, the number of warts increasing. On the $76^{\text {th }}$ day, the young medusa was $3 \mathrm{~cm}$ in diameter, the manubrium was $5.3 \mathrm{~cm}$ long, there were 8 tentacles and the beginning of the gonads was noted.

The long rearing period (compared to the Chrysaora ephyra) and the appearance of gonadal tissue indicate that the specimen had achieved the maximum number of tentacles (totaling 8). The presence of 8 marginal tentacles is diagnostic for the genus Pelagia. Nevertheless, specific identification was hindered due to the small size of the medusa. For the Brazilian coast, the species Pelagia noctiluca (Forskål, 1775) is reported off the Pernambuco and Santa Catarina states (Migotto et al., 2002). 


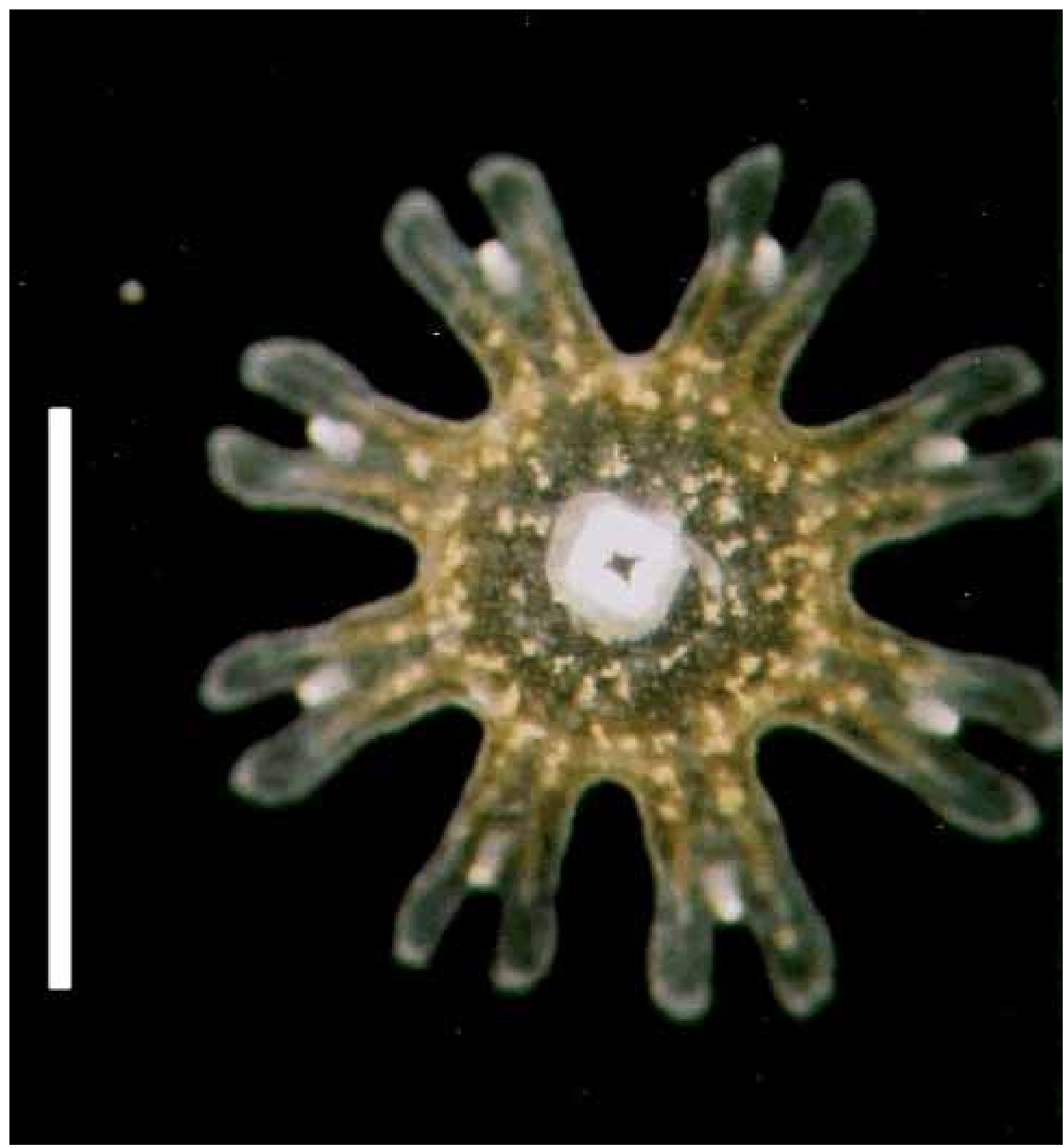

Figure 2. Oral view of ephyra of Phyllorhiza punctata von Lendenfeld, 1884, collected in the Cananéia lagoon estuarine system in January 2002, two days after collecting. Note the zooxanthellae and rounded lappets. Scale bar $=1 \mathrm{~mm}$. 


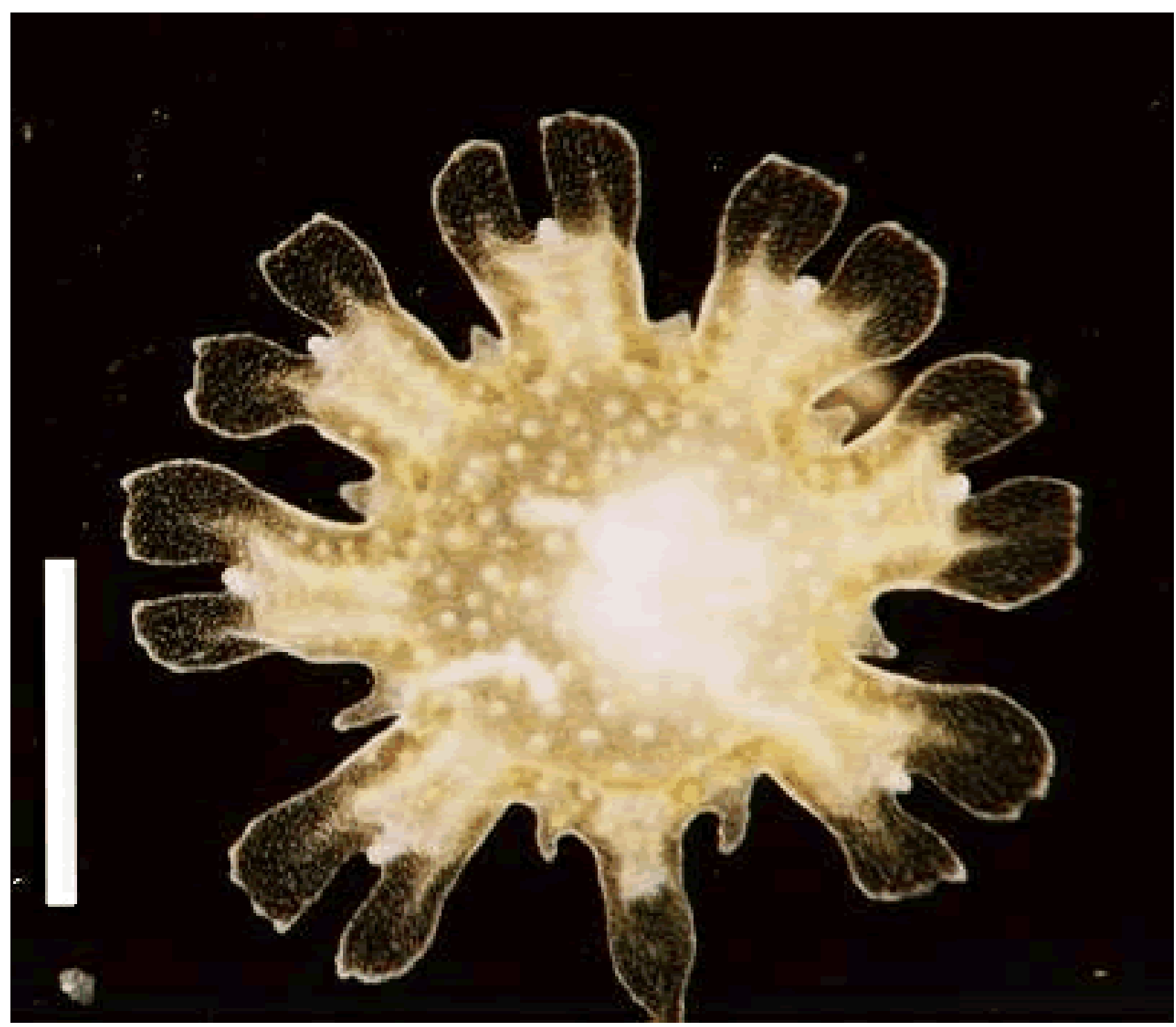

Figure 3. Oral view of ephyra of Phyllorhiza punctata von Lendenfeld, 1884, collected in the Cananéia lagoon estuarine system in April 2001, seven days after collecting. Note the zooxanthellae, the beginning of lappet formation and the exumbrellar warts. Scale bar $=1 \mathrm{~mm}$ 


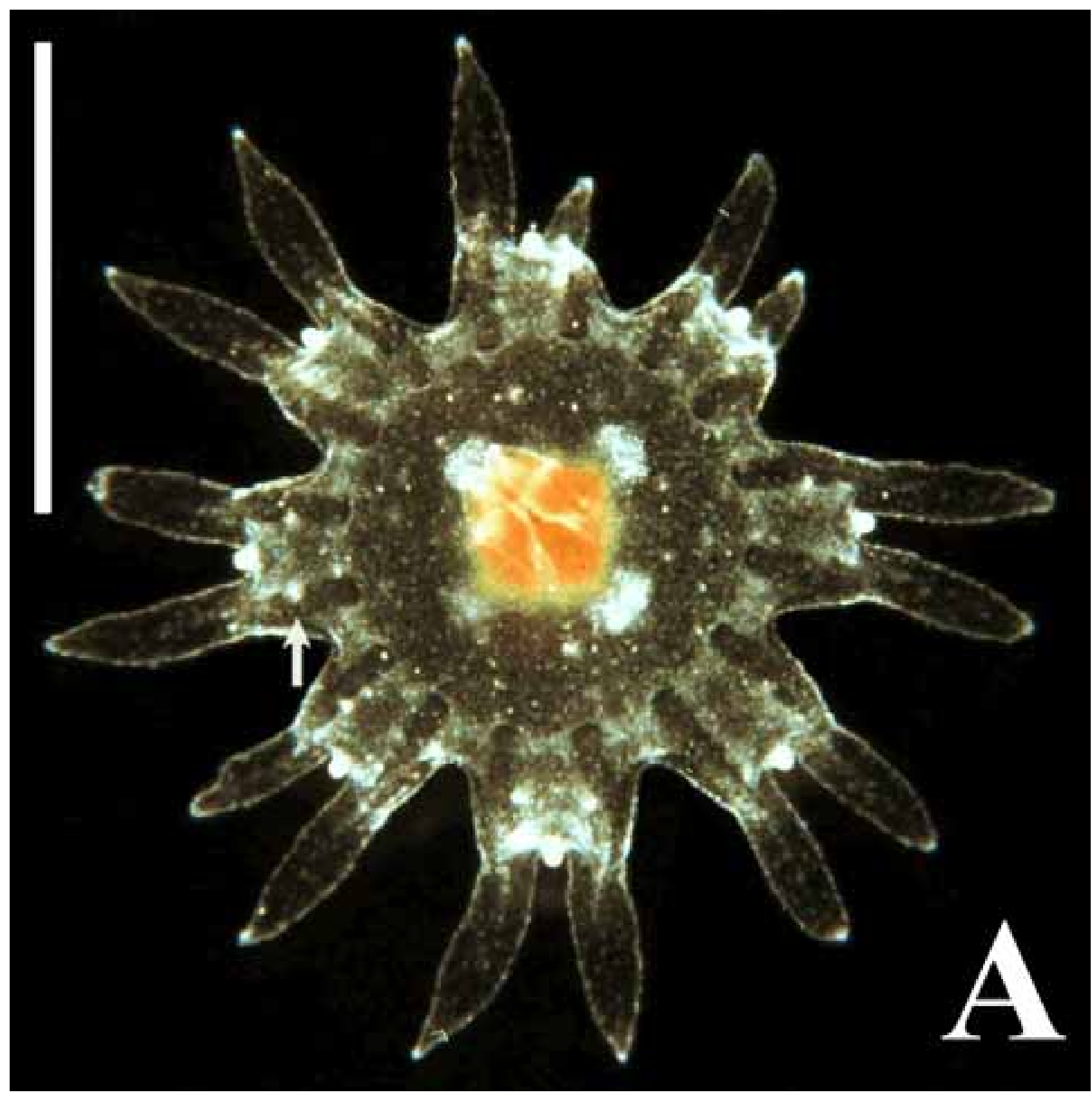

Figure 4. A. Oral view of ephyra of Chrysaora lactea Eschscholtz, 1829, collected in the São Sebastião Channel in August 1999, two days after collecting. Note the red pigment on the manubrium, the nematocyst clusters (arrows) and the pointed lappets. Scale bar $=1 \mathrm{~mm} . \mathbf{B}$. Oral view of just released ephyra of Chrysaora lactea Eschscholtz, 1829, from laboratory cultures. Note the absence of pigmentation, and the nematocyst clusters (arrows). Scale bar $=1 \mathrm{~mm}$ 


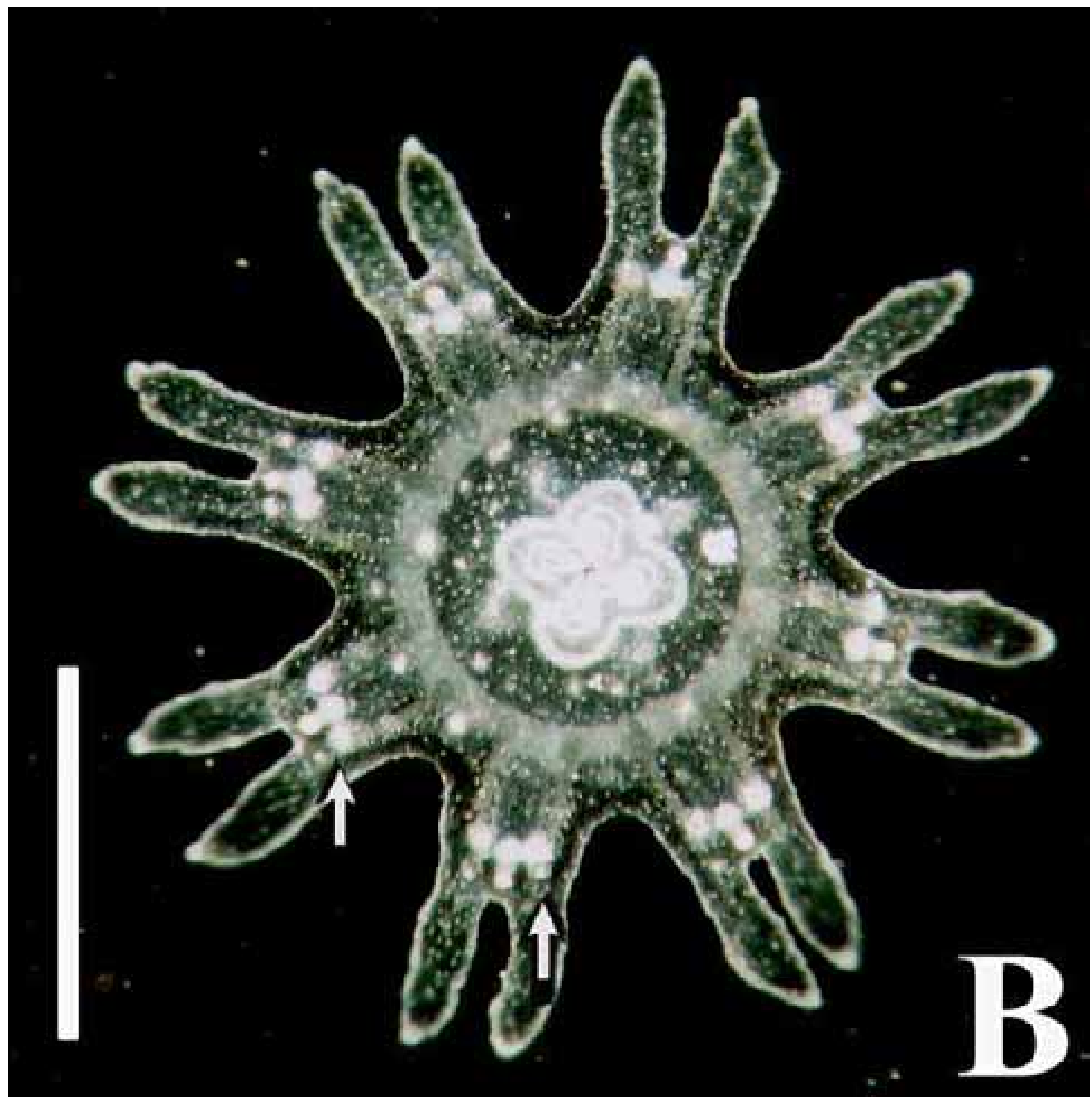

Figure 4. A. Oral view of ephyra of Chrysaora lactea Eschscholtz, 1829, collected in the São Sebastião Channel in August 1999, two days after collecting. Note the red pigment on the manubrium, the nematocyst clusters (arrows) and the pointed lappets. Scale bar $=1 \mathrm{~mm} . \boldsymbol{B}$. Oral view of just released ephyra of Chrysaora lactea Eschscholtz, 1829, from laboratory cultures. Note the absence of pigmentation, and the nematocyst clusters (arrows). Scale bar $=1 \mathrm{~mm}$ 


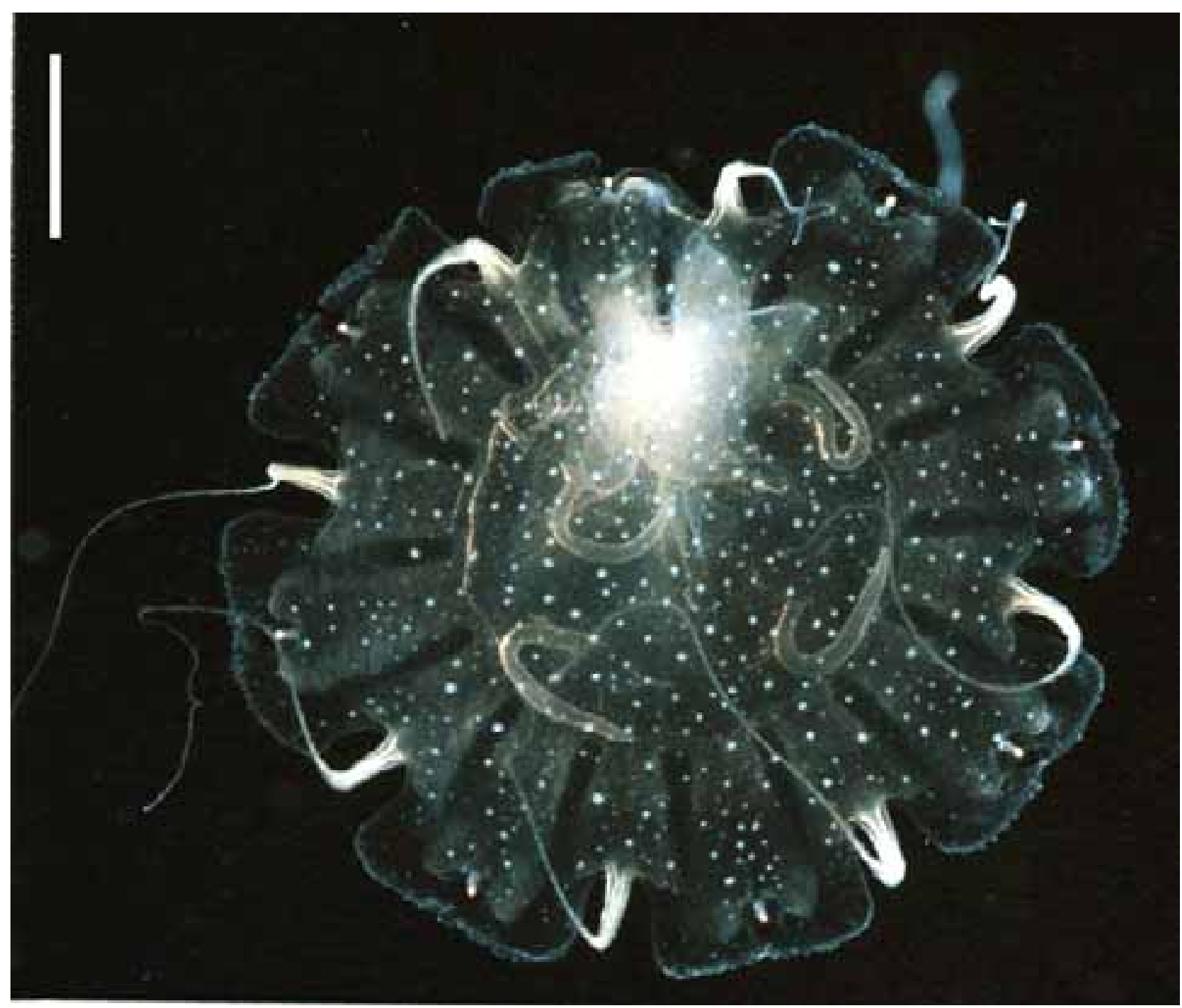

Figure 5. Oral view of ephyra of Chrysaora lactea Eschscholtz, 1829, collected in the São Sebastião Channel in August 1999, 26 days after collecting. Note the absence of red pigment on the manubrium and the already developed primary tentacles. Scale bar $=2 \mathrm{~mm}$. 


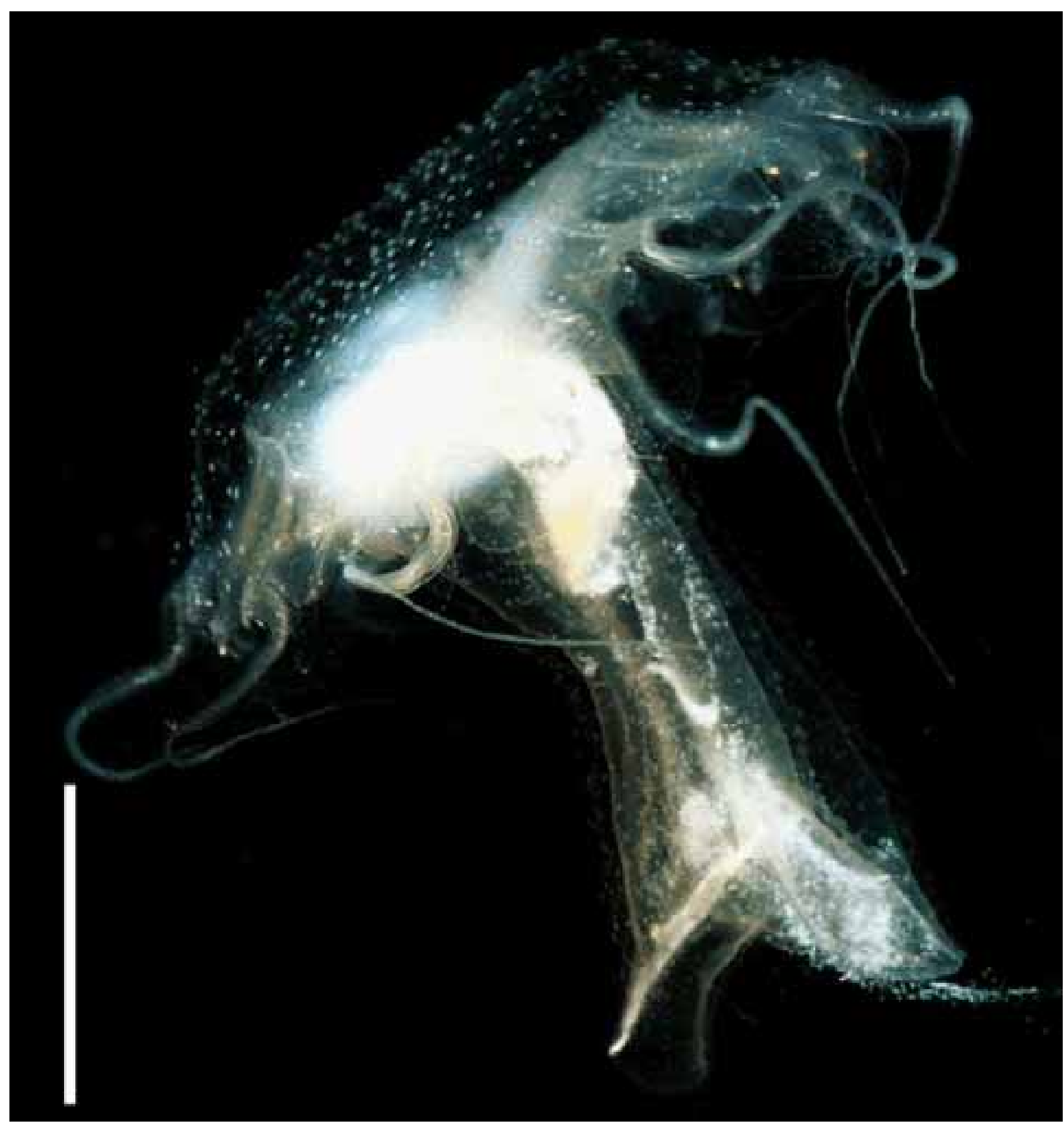

Figure 6. Lateral view of young medusa of Chrysaora lactea Eschscholtz, 1829, collected in the São Sebastião Channel in August 1999, 32 days after collecting. Note the elongated manubrium, , there was food in the manubrium and stomach. Scale bar $=1 \mathrm{~cm}$. 


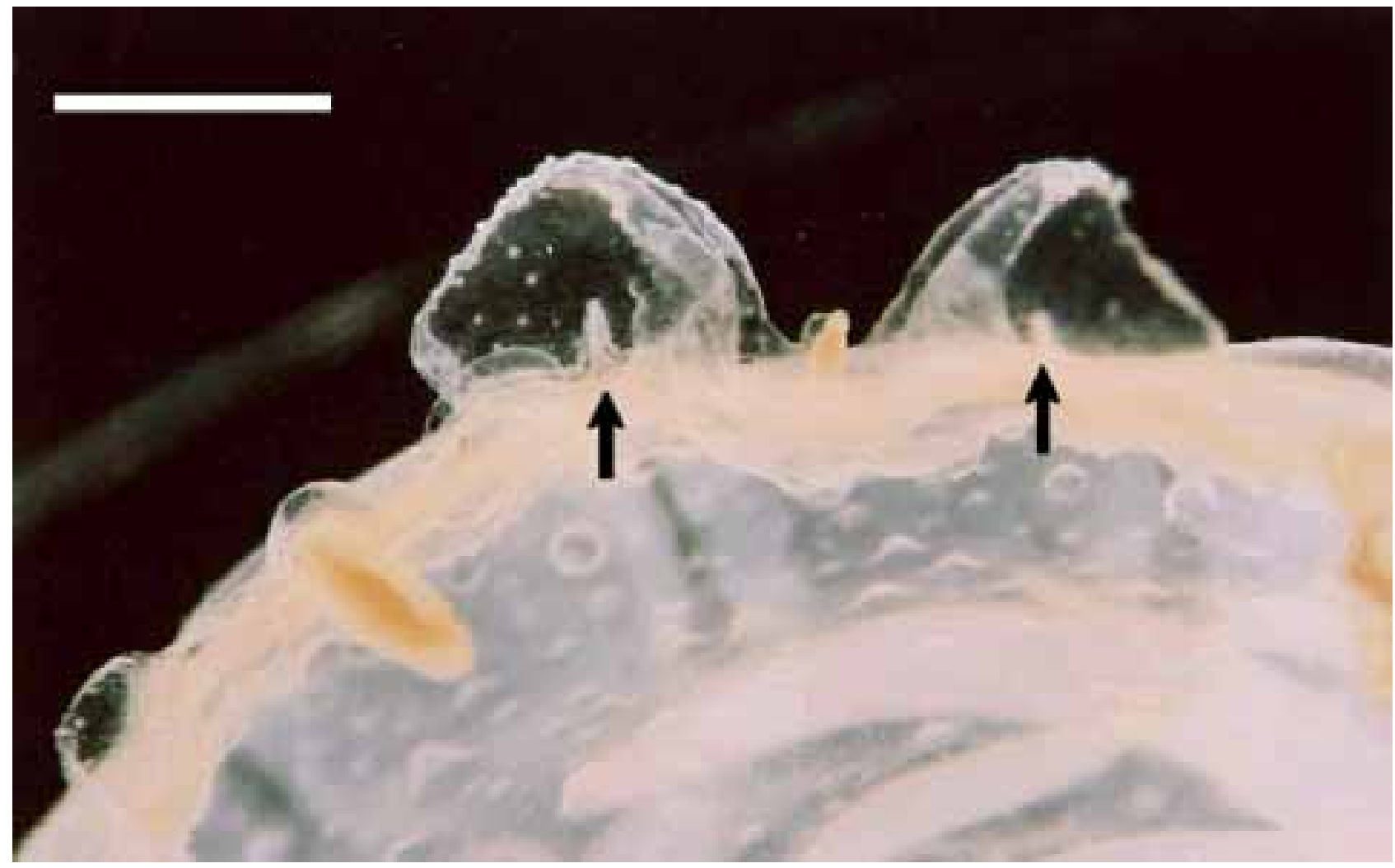

Figure 7. Detail of umbrella margin of preserved young medusa of Chrysaora lactea Eschscholtz, 1829, collected in the São Sebastião Channel in August 1999, 38 days after collecting. Note the small secondary tentacles arising from below the marginal lappets (arrows). Scale bar $=2.5 \mathrm{~mm}$. 


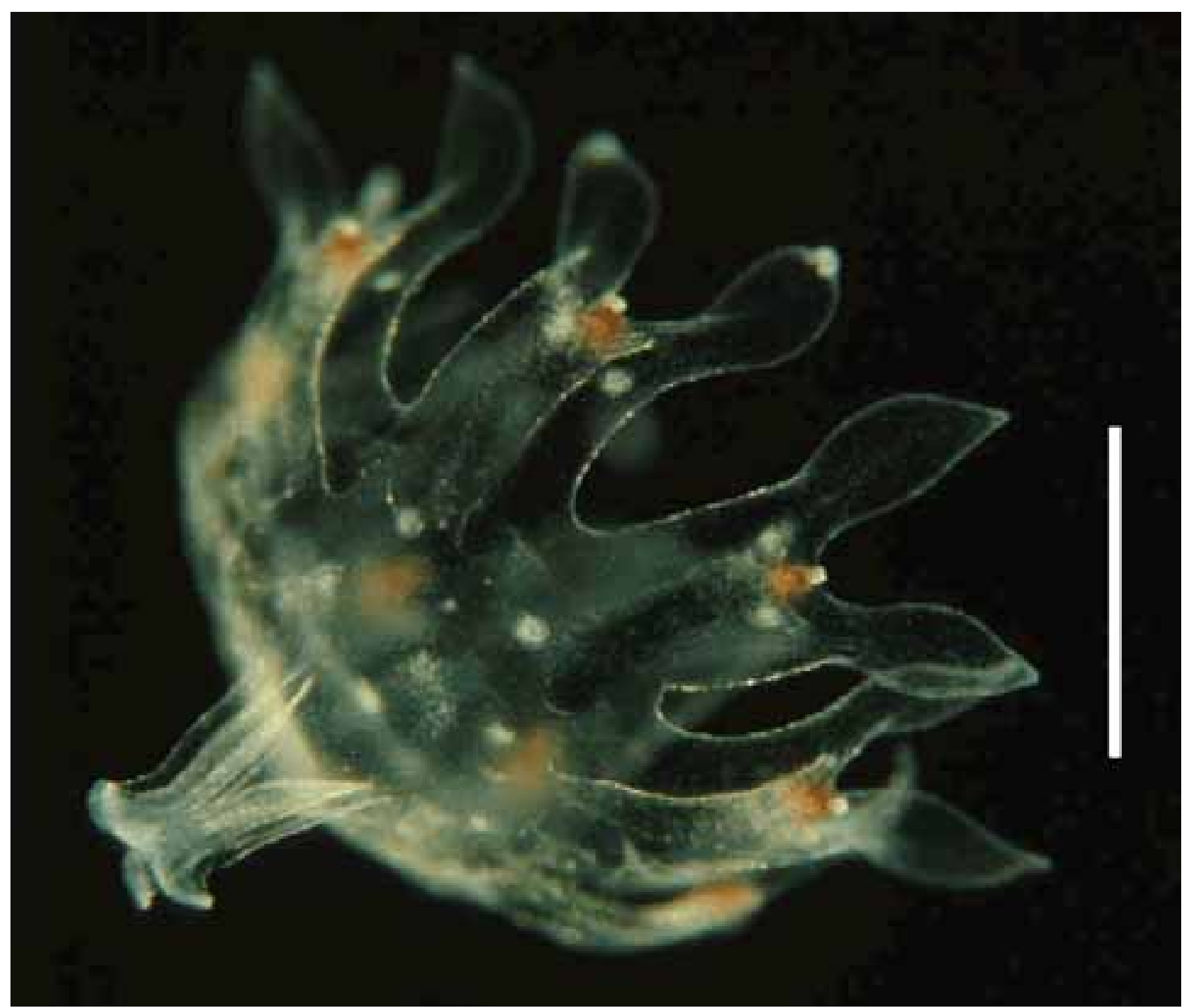

Figure 8. Lateral view of ephyra, upstroke, of Pelagia Péron \& Lesueur, 1810, collected in the São Sebastião Channel in October 1999, nine days after collecting. Note pointed lappets. Scale bar $=2 \mathrm{~mm}$. 


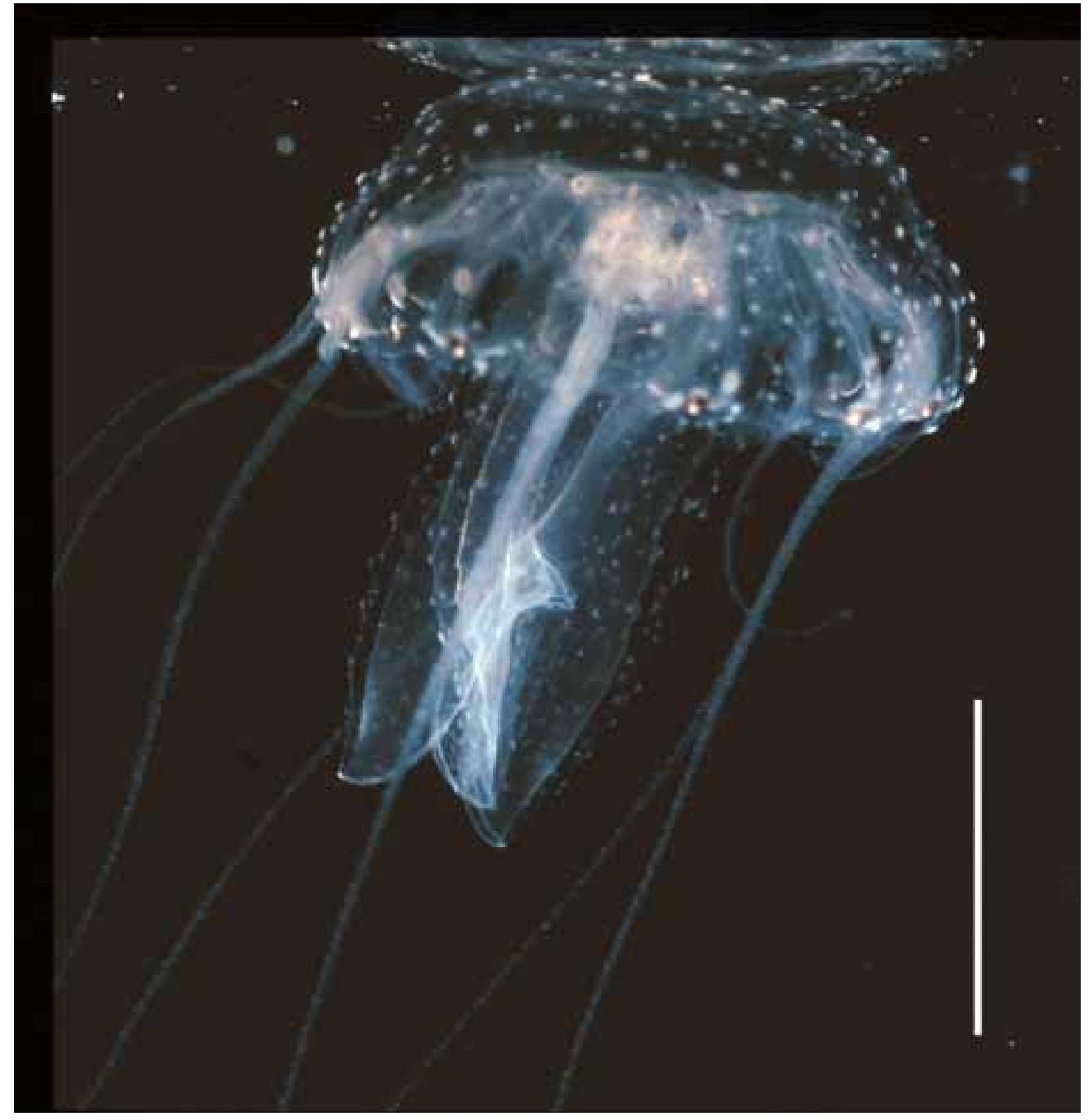

Figure 9. Lateral view of a young medusa of Pelagia Péron \& Lesueur, 1810, collected in the São Sebastião Channel in October 1999, 35 days after collecting. Note the warts on the umbrella and manubrium. Scale bar $=3 \mathrm{~mm}$. 


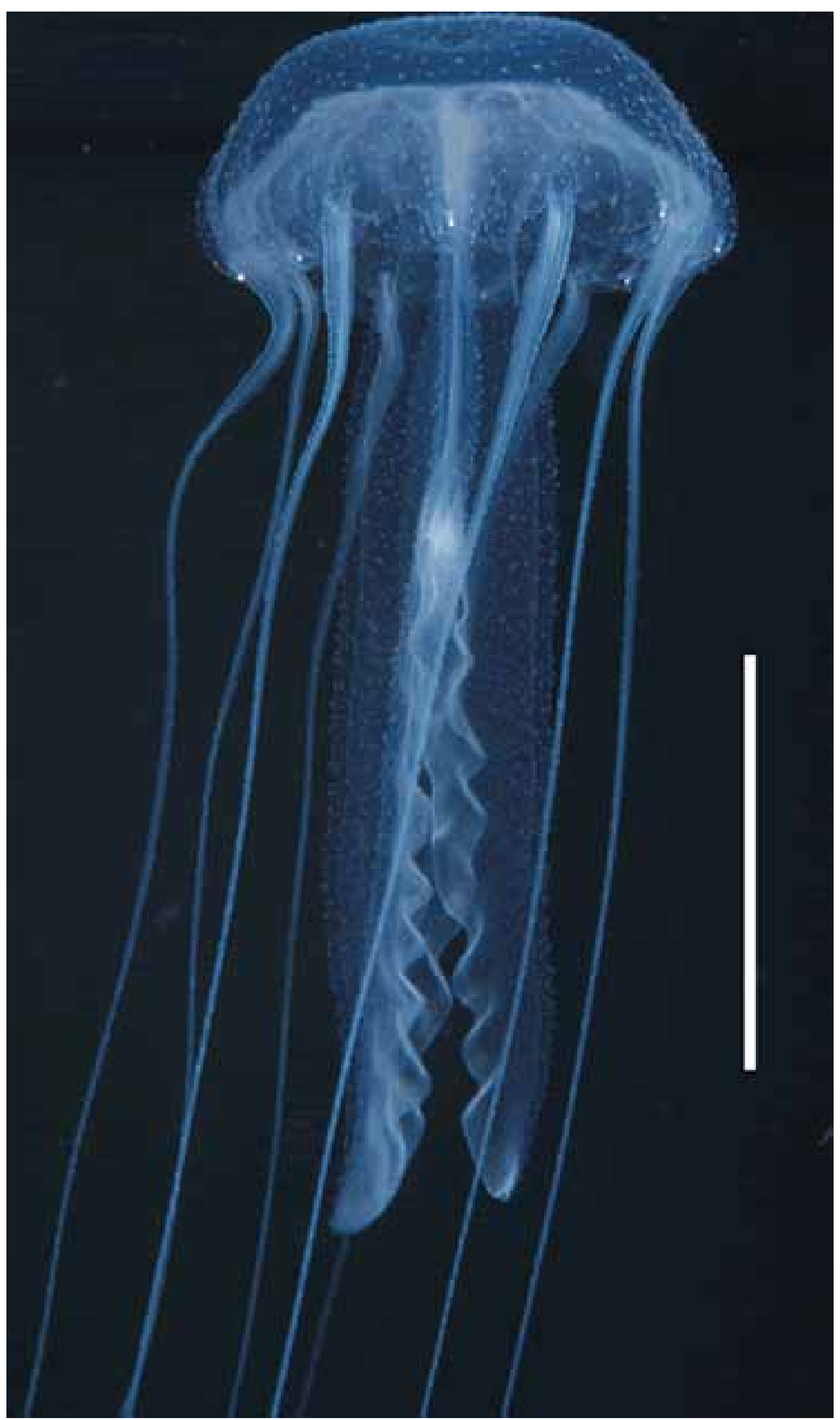

Figure 10. Lateral view of a young medusa of Pelagia Péron \& Lesueur, 1810, sampled in the São Sebastião Channel in October 1999, 71 days after collecting. Note the elongated manubrium. Scale bar $=2 \mathrm{~cm}$. 


\section{Acknowledgements}

We are grateful to Dr Fábio L. da Silveira (IB-USP, Brazil) for assistance and the critical reading of the manuscript. We also thank the Departamento de Zoologia (IB$\underline{\text { USP)}}$, Instituto Oceanográfico da Universidade de São Paulo $\underline{\text { (IO-USP), and Centro de Biologia Marinha (CEBIMar-USP) }}$ for providing collecting and logistic support. Dr. H.W. Mianzan (INIDEP, Argentina) and MSc. A. Lindner (Duke University, USA) provided important literature. VBT and AEM had financial support from the Conselho Nacional de Desenvolvimento Científico e Tecnológico (CNPq) and from CAPES/DS/PROAP. ACM received financial support from the Fundação de Amparo à Pesquisa do Estado de São Paulo (FAPESP 99/05374-7).

\section{References}

ARAI, M.N., 1997. A Functional Biology of Scyphozoa. Chapman \& Hall, London, 316 p.

AVIAN, M., 1986. Biological cycle of Cotylorhiza tubercolata (Macri 1778): morphological aspects of the development from ephyra to young medusa. Nova Thalassia, 8(suppl.2): 47-58.

BIGELOW, R.P., 1900. The anatomy and development of Cassiopea xamachana. Mem. Boston Soc. Nat. Hist., 5: 193-237.

CALDER, D.R., 1972. Development of the sea nettle Chrysaora quinquecirrha (Scyphozoa, Semaeostomeae). Ches. Sci., 13: 40-44.

CALDER, D.R., 1973. Laboratory observations on the life history of Rhopilema verrilli (Scyphozoa: Rhizostomeae). Mar. Biol., 21: 109-114.

CALDER, D.R., 1982. Life history of the cannonball jellyfish, Stomolophus meleagris L. Agassiz, 1860 (Scyphozoa, Rhizostomida). Biol. Bull., 162: 149-162.

COLLINS, A.G., 2002. Phylogeny of Medusozoa and the evolution of cnidarian life cycles. J. Evol. Biol., 15: 418432.

D'AMBRA, I.; J.H. COSTELLO \& F. BENTIVEGNA, 2001. Flow and prey capture by the scyphomedusa Phyllorhiza punctata von Lendenfeld, 1884. Hydrobiologia, 451 (Dev. Hydrobiol. 155): 223-227.

DELAP, M.J., 1901. Notes on the rearing of Chrysaora isosceles in an aquarium. Ir. Nat., 10: 25-28.

DING, G. \& J. CHEN, 1981. The life history of Rhopilema esculenta Kishinouye. J. Fish. China, 5: 93-104. [In Chinese]
GARCÍA, J.R., 1990. Population dynamics and production of Phyllorhiza punctata (Cnidaria: Scyphozoa) in Laguna Joyuda, Puerto Rico. Mar. Ecol. Prog. Ser., 64: 243251.

GERSHWIN, L., 2001. Systematics and biogeography of the jellyfish Aurelia labiata (Cnidaria: Scyphozoa). Biol. Bull., 201: 104-119.

GERSHWIN, L. \& A.G. COLLINS, 2002. A preliminary phylogeny of Pelagiidae (Cnidaria, Scyphozoa), with new observations of Chrysaora colorata comb. nov. J. Nat. Hist., 36(2): 127-148.

GOETTE, A., 1893. Vergleichende Entwicklungsgeschichte von Pelagia noctiluca Pér. Z. wiss. Zool., 55: 645-695.

GOHAR, H.A.F. \& A.M. EISAWY, 1960. The development of Cassiopea andromeda. Publ. Mar. Biol. Sta., AlGhardaqa, 11: 148-190.

GOY, J. 1979. Campagne de la Calypso au large des côtes atlantiques de l'Amérique du Sud (1961-1962) - 35. Méduses. Rés. scient. Camp. Calypso, 11: 263-296.

GREVE, W., 1968. The "planktonkreisel”, a new device for culturing zooplankton. Mar. Biol., 1: 201-203.

GRÖNDAHL, F., 1988. A comparative ecological study on the scyphozoans Aurelia aurita, Cyanea capillata and C. lamarckii in the Gullmar Fjord, western Sweden, 1982 to 1986. Mar. Biol., 97: 541-550.

HAECKEL, E. 1880. Das system der medusen. I, 2: System der Acraspeden. Zweite Hälfte des Systems der Medusen. Gustav Fischer, Jena, 361-672.

JARMS, G., 1990. Neubeschreibung dreier Arten der Gattung Nausithoe (Coronata, Scyphozoa) sowie Wiederbeschreibung der Art Nausithoe marginata Kölliker, 1853. Mitt. hamb. zool. Mus. Inst., 87: 7-39.

JARMS, G., 1997. The polyps of Coronatae (Scyphozoa), a review and some new results. In: den HARTOG, J.C. (ed.), Proceedings of the $6^{\text {th }}$ International Conference on Coelenterate Biology, 1995. Nationaal Natuurhistorisch Museum, Leiden, p. 271-278.

JARMS, G., 2001. The life cycle of Nausithoe hagenbecki sp. nov. (Scyphozoa, Coronatae). Mitt. hamb. zool. Mus. Inst., 98: 13-22.

JARMS, G.; U. BÅMSTEDT; H. TIEMANN; M.B. MARTINUSSEN \& J.H. FOSSÅ, 1999. The holopelagic life cycle of the deep-sea medusa Periphylla periphylla (Scyphozoa, Coronatae). Sarsia, 84: 55-65.

JARMS, G.; A.C. MORANDINI \& F.L. da SILVEIRA, in press. Methods and experiences with cultivating polyps and medusae of Coronatae (Cnidaria, Scyphozoa) with a review of important characters. Helgol. Mar. Res. 
KAKINUMA, Y., 1967. Development of a scyphozoan, Dactylometra pacifica Goette. Bull. Mar. Biol. Sta. Asamushi, 13: 29-32.

KAWAGUTI, S. \& A. MATSUNO, 1981. A new species of the Coronatae, Scyphozoa, from the Japan Sea; Atorella japonica n.sp. Bull. Kawasaki Paramed. coll., 1: 15-21.

KIKINGER, R., 1992. Cotylorhiza tuberculata (Cnidaria: Scyphozoa) - life history of a stationary population. P.S.Z.N. I: Mar. Ecol., 13(4): 333-362.

KIKINGER, R. \& L. von SALVINI-PLAWEN, 1995. Development from polyp to stauromedusa in Stylocoronella (Cnidaria: Scyphozoa). J. mar. biol. Ass. U. K., 75: 899912.

KOMAI, T. \& Y. TOKUOKA, 1939. Further observations on the strobilation of Stephanoscyphus. Mem. Coll. Sci., Kyoto Imp. Univ., ser. B, 15(2): 127-133.

LANGE, J. \& R. KAISER, 1995. The maintenance of pelagic jellyfish in the Zoo-Aquarium Berlin. Int. Zoo Yb., 34: 59-64.

LITTLEFORD, R.A., 1939. The life cycle of Dactylometra quinquecirrha. L. Agassiz in the Chesapeake Bay. Biol. Bull., 77: 368-381.

LOTAN, A.; R. BEN-HILLEL \& Y. LOYA, 1992. Life cycle of Rhopilema nomadica: a new immigrant scyphomedusan in the Mediterranean. Mar. Biol., 112: 237-242.

LUCAS, C.H., 2001. Reproduction and life history strategies of the common jellyfish, Aurelia aurita, in relation to its ambient environment. Hydrobiologia, 451 (Dev. Hydrob. 155): 229-246.

MIANZAN, H.W., 1989a. Las medusas Scyphozoa de la Bahía Blanca, Argentina. Bolm Inst. oceanogr., 37(1): 2932.

MIANZAN, H.W., 1989b. Sistematica y zoogeografía de Scyphomedusae en aguas neriticas argentinas. Invest. Mar. CICIMAR, 4(1): 15-34.

MIANZAN, H.W. \& P.F.S. CORNELIUS, 1999. Cubomedusae and Scyphomedusae. In: D. BOLTOVSKOY (ed.), South Atlantic Zooplankton, Vol. I. Blackhuys Publishers, Leiden, 513-559 pp.

MIGOTTO, A.E.; A.C. MARQUES; A.C. MORANDINI \& F.L. da SILVEIRA, 2002. Checklist of the Cnidaria Medusozoa of Brazil. Biota Neotropica, 2(1), 30p.

ORTIZ-CORP'S, E.; C.E. CUTRESS \& B.M. CUTRESS, 1987. Life history of the coronate scyphozoan Linuche unguiculata (Swartz, 1788). Carib. J. Sci., 23: 432-443.

PASPALEFF, B.W., 1938. Über die Entwicklung von Rhizostoma pulmo Agass. Arb. biol. Meeresst Varna, 7: 1-17.

PITT, K.A., 2000. Life history and settlement preferences of the edible jellyfish Catostylus mosaicus (Scyphozoa: Rhizostomeae). Mar. Biol., 136: 269-279.
RIPPINGALE, R.J. \& S.J. KELLY, 1995. Reproduction and survival of Phyllorhiza punctata (Cnidaria: Rhizostomeae) in a seasonally fluctuating salinity regime in western Australia. Mar. Freshw. Res., 46: 11451151.

ROTTINISANDRINI, L. \& M. AVIAN, 1983. Biological cycle of Pelagia noctiluca: morphological aspects of the development from planula to ephyra. Mar. Biol., 74: 169174.

RUSSELL, F.S., 1970. The medusae of the British Isles II. Pelagic Scyphozoa with a supplement to the first volume on hydromedusae. Cambridge University Press, Cambridge, 284 pp.

RUSSELL, F.S. \& W.J. REES, 1960. The viviparous scyphomedusa Stygiomedusa fabulosa Russell. J. mar. biol. Ass. U. K., 39: 303-322.

SCHUCHERT, P., 1993. Phylogenetic analysis of the Cnidaria. Z. zool. syst. evolutionsforsch., 31: 161-173.

SILVEIRA, F.L. da \& A.C. MORANDINI, 1997. Nausithoe aurea n. sp. (Scyphozoa, Coronatae, Nausithoidae), a species with two pathways of reproduction after strobilation: sexual and asexual. Contr. Zool., 66(4): 235-246.

SILVEIRA, F.L. da \& A.C. MORANDINI, 1998. Asexual reproduction in Linuche unguiculata (Swartz, 1788) (Scyphozoa: Coronatae) by planuloid formation through strobilation and segmentation. Proc. biol. Soc. Wash., 111(4): 781-794.

SÖTJE, I. \& G. JARMS, 1999. Detailed description of Thecoscyphus zibrowii Werner, 1984 (Scyphozoa, Coronatae) with remarks on the life cycle. Mitt. hamb. zool. Mus. Inst., 96: 5-13.

STACHOWITSCH, M., 1992. The invertebrates. An illustrated glossary. New York, Wiley. [Scyphozoa: 19-24 + one unnumbered plate.]

SUGIURA, Y., 1966. On the life history of rhizostome medusae. IV. Cephea cephea. Embryologia, 9: 105-122.

UCHIDA, T., 1926. The anatomy and development of a rhizostome medusa, Mastigias papua L.Agassiz, with observations on the phylogeny of Rhizostomae. J. Fac. Sci., Imp. Univ. Tokyo, Sec. VI - Zool., 1(1): 45-95.

UCHIDA, T., 1929. Studies on the Stauromedusae and Cubomedusae, with special reference to their metamorphosis. Jap. J. Zool., 2(2): 103-193.

UCHIDA, T. \& Y. SUGIURA, 1978. On the polyp of the scyphomedusa, Sanderia malayensis and its reproduction. J. Fac. Sci., Hokkaido Univ. (Zool.), 21, 279-286.

WERNER, B., 1966. Stephanoscyphus (Scyphozoa, Coronatae) und seine direkte Abstammung von den fossilen Conulata. Helgoländer wiss. Meeresunters., 13: 317-347. 
WERNER, B., 1974. Stephanoscyphus eumedusoides n. spec. (Scyphozoa, Coronatae) ein Höhlenpolyp mit einem neuen Entwicklungsmodus. Helgoländer wiss. Meeresunters., 26: 434-463.

WERNER, B., 1979. Coloniality in the Scyphozoa: Cnidaria. In: D. LARWOOD \& B.R. ROSEN (eds.), Biology and systematics of colonial organisms, Academic Press, London, 81-103 pp.

WERNER, B. \& J. HENTSCHEL, 1983. Apogamous life cycle of Stephanoscyphus planulophorus. Mar. Biol., 74: 301304.

WROBEL, D. \& C.E. MILLS, 1998. Pacific coast pelagic invertebrates. A guide to the common gelatinous animals. Sea Challengers \& Monterrey Bay Aquarium, Monterrey, $108 \mathrm{p}$.

Title: On the occurrence of scyphozoan ephyrae (Cnidaria, Scyphozoa, Semaeostomeae and

Rhizostomeae) in the southeastern Brazilian coast

Authors: Valquiria Baddini Tronolone, André Carrara

Morandini,, Alvaro Esteves Migotto

Biota Neotropica, Vol. 2 (number 2): 2002

http://www.biotaneotropica.org.br/v2n $2 / \mathrm{pt} /$ a bs tract ? a r t i c le + B N 02102022002

Date Received 07/04/2002

Revised 08/03/2002

Accepted 10/02/2002

ISSN 1676-0611

http://www.biotaneotropica.org.br 